\title{
In vitro \& ex vivo Acetylcholinesterase Inhibitory Activity of Morinda citrifolia Linn (Noni) Fruit Extract
}

\author{
Srikanth Jeyabalan ${ }^{1 *}$, Kavimani Subramanian², Uma Maheswara Reddy Cheekala ${ }^{3}$, Chitra Krishnan ${ }^{4}$
}

\section{Srikanth Jeyabalan ${ }^{1 *}$, Kavimani Subramanian², Uma Maheswara Reddy Cheekala ${ }^{3}$, Chitra Krishnan ${ }^{4}$}

'Department of Pharmacology, Faculty of Pharmacy, Sri Ramachandra University, Porur, Chennai - 600 116, Tamil Nadu, INDIA 2Department of Pharmacology, Mother Theresa Post Graduate and Research Institute of Health Sciences, Puducherry - 605006, INDIA

${ }^{3}$ Department of Pharmacology, Faculty of Pharmacy, Sri Ramachandra University, Porur, Chennai - 600 116, Tamil Nadu, INDIA

${ }^{4}$ Department of Pharmaceutical chemistry, Faculty of Pharmacy, Sri Ramachandra University, Porur, Chennai - 600116 , Tamil Nadu, INDIA

Correspondence

\section{Srikanth Jeyabalan}

Department of Pharmacology, Faculty of Pharmacy, Sri Ramachandra University, Porur, Chennai - 600116, Tamil Nadu, INDIA

Phone no: +919094020093

E-mail: srikanth.j@sriramachandra.edu.in History

- Submission Date: 17-02-2017:

- Review completed: 18-05-2017;

- Accepted Date: 31-08-2017.

DOI : 10.5530/pj.2017.6.141

Article Available online

http://www.phcogj.com/v9/i6

Copyright

(c) 2017 Phcog.Net. This is an openaccess article distributed under the terms of the Creative Commons Attribution 4.0 International license.

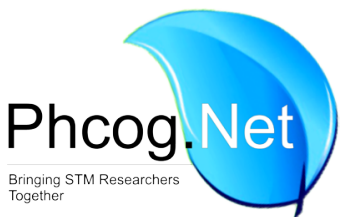

\begin{abstract}
Background: Psychological problem is a key medical issue for numerous neuropsychiatric and neurodegenerative diseases, for example, schizophrenia, Alzheimer's, dementia, seizure and Parkinsonism. Morinda citrifolia (Noni) has been utilized for a considerable length of time to cure or counteract assortment of diseases by conventional therapeutic professionals in Hawaii and Polynesia. Objective: The present study is focused to identify the neuroprotective activity of Morinda citrifolia fruit extract (MCFE) on in vitro and ex vivo animal model by inhibition of acetylcholinesterase (AChE), an enzyme target used for the treatment of Alzheimer's disease. Methods: Acetylcholinesterase inhibition assay was performed by in vitro \& ex vivo methods as described by Ellman et al. In vitro antioxidant assay of the extract was performed by DPPH free radical scavenging activity \& nitric oxide scavenging activity. Statistical analysis used: Statistical analysis was carried out using non linear regression analysis for plotting the line of best fit for the observed values using GraphPad Prism software. Results: By performing in vitro antioxidant assay the $\mathrm{IC}_{50}$ value of the standard quercetin was found to be $46.22 \mu \mathrm{g} / \mathrm{ml}$ as compared to the MCFE which has an IC value of $43.14 \mathrm{\mu g} / \mathrm{ml}$ for DPPH free radical scavenging activity. Similarly the $I C_{50}$ value of the standard ascorbic acid was found to be $81.85 \mu \mathrm{g} / \mathrm{ml}$ as compared to the MCFE which has an $\mathrm{IC}_{50}$ value of $148.0 \mu \mathrm{g} / \mathrm{ml}$ for nitric oxide scavenging activity. Acetylcholinesterase inhibition assay was performed by in vitro method and the $I C_{50}$ value of MCFE and neostigmine was found to be $31.84 \mu \mathrm{g} / \mathrm{ml} \& 19.71 \mu \mathrm{g} / \mathrm{ml}$ respectively. Conclusions: The present study investigated the neuroprotective activity of MCFE and it was identified by both in vitro and ex vivo techniques that the phytoconstituents has the ability to improve the learning and memory function by inhibiting the acetylcholinesterase.
\end{abstract}

Key words: Morinda citrifolia, Noni, Acetylcholinesterase, Neuroprotective activity, in vitro, ex vivo.

Key Messages: The present study investigated the neuroprotective activity of Morinda citrifolia and it was identified by both in vitro and ex vivo techniques that the phytoconstituents in the plant can improve the learning and memory function by inhibiting the acetylcholinesterase. Further the antioxidant potential of the plant was also evident from the DPPH and nitric oxide scavenging activity. Future studies may be designed for chronic administration of Morinda citrifolia to further investigate the effect on in vivo experimentation and also to identify the safety and efficacy parameters at both preclinical and clinical stages.

\section{INTRODUCTION}

Psychological problem is a key medical issue for numerous neuropsychiatric and neurodegenerative disorders like schizophrenia, Alzheimer's, dementia, seizure and Parkinsonism. Cholinergic framework is considered as one of the key part in the control of learning and memory functions. Cholinesterase inhibitors increase the cholinergic transmission specifically by preventing acetylcholinesterase (AChE) which hydrolyses acetylcholine. ${ }^{1}$ Incredible significance has been given for the identification of neurotransmitter component concerned in the characteristic indication of neurological and psychiatric disorders. ${ }^{2}$ Acetylcholinesterase has been ended up

being the most conceivable remedial focus for the indicative management of Alzheimer's disease. Acetylcholinesterase is a constituent of the $\alpha / \beta$ hydrolase protein super family, playing a significant role in acetylcholine-interceded neurotransmission. Lately, the part of AChE inhibitors was reassessed from neurotoxins to neuron-defensive in the disorders with disruption in cholinergic transmission. ${ }^{3}$

Besides, research in animal models has demonstrated that the combination therapy with memantine and the AChE inhibitors can enhance memory than either treatment alone with the single drug. In the clinical setting, blend treatment

Cite this article: Jeyabalan S, Subramanian K, Cheekala UMR, Krishnan C. In vitro \& ex vivo Acetylcholinesterase Inhibitory Activity of Morinda citrifolia Linn (Noni) Fruit Extract. Pharmacog J. 2017;9(6):900-5. 
Jeyabalan et al.: In vitro \& ex vivo acetylcholinesterase inhibitory activity of Morinda citrifolia

with memantine and an AChE inhibitor has proved to be an appreciated progress for the treatment of patients with Alzheimer's disease. ${ }^{4}$ Mankind is gifted with plenty of plant based natural sources of drugs. The various collections of bioactive nutrients available in these natural food plays an essential function in avoidance and healing of various neurodegenerative diseases, such as Alzheimer's, Parkinsonism and other neuronal disorders. Aggregated confirmation recommends that the phytoconstituents, for example, polyphenolic cell reinforcements found in natural products, vegetables, herbs and nuts, may conceivably frustrate neurodegeneration, and improve memory and intellectual capacity. ${ }^{5}$

Phytochemicals from medicinal plants assume a fundamental part in maintaining the mental balance regulated by the function of receptors for the major inhibitory neurotransmitters. As per study, the natural pharmaceuticals utilized as a part of Ayurvedic and Chinese medicines contain various phytoconstituents with neuroprotective impact which may be helpful in neuropsychiatric and neurodegenerative disorders. ${ }^{6}$

Morinda citrifolia Linn belongs to the family Rubiaceae and habituated to Sub-himalayan tracts, Darjeeling, Konkan and Andamans. The Indian Mulberry is commonly known as ashyuka, akshi \& atchy in Ayurveda \& nunaa, togaru in Siddha. ${ }^{7}$ Morinda citrifolia (Noni) has been utilized for a considerable length of time to cure or counteract assortment of diseases by conventional therapeutic professionals in Hawaii and Polynesia. A complete review on Morinda citrifolia was performed by Assi et al in 2016 which described the antimicrobial and antiseptic activity, antifungal activity, antioxidant activity, anti-inflammatory activity, anti-arthritic activity, anti-cancer activity, antidiabetic activity, wound healing activity, memory enhancing activity, anxiolytic and sedative activity, analgesic activity, gastric ulcer healing activity, antiemetic activity, gout and hyperuricemia healing activity, immunity enhancing activity, anti-viral activity, anti-parasitic activity, anti-tuberculosis activity, osteoporotic and otoscopic enhancer. These activities were carried out to the extent of in-vitro, in-vivo \& clinical trial stages. ${ }^{8}$

The neuroprotective effect of an ethyl acetate fruit extract of Morinda citrifolia (Rubiaceae) Linn at doses of 200 and $400 \mathrm{mg} / \mathrm{kg}$, po was contemplated by Muralidharan et al. ${ }^{9}$ Past study by Pachauri et al. was intended to examine impact of Noni on memory, cerebral blood flow(CBF), oxidative stress and AChE action in scopolamine incited amnesia mice model. ${ }^{10}$ Harada et al. inspected the impact of the juice of Morinda citrifolia (Noni juice) on the brain damage brought about by ischemic stress in mice. ${ }^{11}$ In our past study we reported the antiepileptic activity of Morinda citrifolia Linn fruit extract against seizures instigated by Maximal Electro Shock (MES) technique in rats. ${ }^{12}$

Köktürk et al assessed the neuroprotective impacts of Morinda citrifolia L. (Rubiaceae), regularly known as Noni, and memantine on hydrocephalus-actuated neurodegenerative disorders. ${ }^{13}$ Pandy et al showed the antidopaminergic impact of Morinda citrifolia Linn. ${ }^{14}$ The discoveries by Muto et al recommended that the association of Noni fruit juice shields brain from stress-instigated impedance of psychological capacity and that this defensive impact might be identified with change in stressinitiated diminishes in vein thickness in the hippocampal dentate gyrus. ${ }^{15}$ Harada et al recommended that Noni juice could encourage insulin discharge after ischemic stress and may reduce the advancement of glucose intolerance. These components may add to the neuronal defensive impact of Noni juice against ischemic stress. ${ }^{16}$ Pachauri et al proposed the useful impacts of Noni organic product against streptozotocin-induced memory weakness, which might be ascribed to enhanced mind vitality system, cholinergic neurotransmission and antioxidative activity. ${ }^{17}$ One of the previous study reported in silico acetylcholinesterase inhibitory activity of Morinda citrifolia. ${ }^{18}$ The present study is focused to identify the neuroprotective activity of MCFE on in vitro and ex vivo animal models by inhibition of acetylcholinesterase, an enzyme target used for the management of Alzheimer's disease.

\section{SUBJECTS AND METHODS}

\section{Chemicals}

1,1 Diphenyl -2-picryl hydrazyl hydrate (DPPH), was obtained from Himedia, Mumbai, quercetin, ascorbic acid, was obtained from SRL, Mumbai, trichloroacetic acid, Acetylthiocholine iodate, 5,5 - Dithiobis [2-nitrobenzoic acid], sodium nitroprusside, Griess reagent, Bovine serum albumin, Folin catecheau reagent were purchased from SD Fine Ltd, Mumbai. All other chemicals used in the study was procured from local suppliers and of analytical grade.

\section{Plant Extract}

The full spectrum standardized extract of Morinda citrifolia fruit was obtained from Amsar Goa Pvt Ltd, Goa. The plant was authenticated by Dr Laxmi Morajkar, Head Ayurveda Division (Voucher specimen Number: AGPL/039/13-14). Morinda citrifolia fruits were shade dried and kept in an air tight container. Extraction was carried out with water and ethanol in a ratio of 80:20 by a simple maceration technique. The hydro alcoholic solvent of 1 liter was added to the shade dried plant powder of $100 \mathrm{~g}$ and placed on a mechanical shaker for a period of 4 hours. Then the solution was filtered through Whatman No.1 filter paper. The filtrate concentrated using flash evaporator and further processed to dryness in vacuum desiccators. $4.5 \mathrm{~g}$ was the percentage yield of the hydroalcholic extract of Morinda citrifolia.

\section{Animals}

The ex-vivo study was performed using Swiss albino mice of 20-25 g. The Swiss albino inbred colonies of mice was purchased from Venkateshwara enterprises, Bangalore. The mice were adjusted and assimilated to controlled laboratory condition of Center of Toxicology and Developmental Research (CEFT) with temperature $\left(23 \pm 2^{\circ} \mathrm{C}\right)$, humidity $(50 \pm 5 \%)$ and $12 \mathrm{~h}$ light dark cycles. The experimental animals were randomized in to control and treatment groups and were placed in a sanitized polypropylene cages containing sterile paddy husk as bedding. The animals were freely accessed to standard pellets and water ad libitum. All the studies conducted were approved by the Institutional Ethical Committee, Sri Ramachandra University, Chennai, (IAEC/XLIII/SRU/424/2015).

\section{In vitro antioxidant activity DPPH radical scavenging assay}

The free radical scavenging activity of the plant extracts was examined by the tactic given by Yohozowa et al using staining of ethanolic solution of 1, 1-diphenyl-2-picrylhydrazyl radical (DPPH). ${ }^{19}$ Quercetin was used as a positive control and the ethanolic solution of DPPH was used as a control. The reaction mixture containing $1.9 \mathrm{ml}$ of freshly prepared DPPH $(200 \mu \mathrm{M}$ in ethanol) with various concentrations of the sample MCFE $(25-800 \mu \mathrm{g} / \mathrm{ml})$ was shaken. Discolorations were measured at $517 \mathrm{~nm}$ by using UV Spectrophotometer after incubation of mixture for $20 \mathrm{~min}$ at room temperature. The level of discoloration indicates the free radical scavenging effectiveness of the substances. The Percentage of DPPH free radical scavenging activity was calculated by the following formula:

Percentage DPPH inhibition $(\%)=\left[\left(\mathrm{A}_{\text {blank }}-\mathrm{A}_{\text {sample }}\right) /\left(\mathrm{A}_{\text {blank }}-\mathrm{A}_{\text {control }}\right)\right] \times 100$

Where $\mathrm{A}_{\text {blank }}, \mathrm{A}_{\text {sample }}$ and $\mathrm{A}_{\text {control }}$ are the absorbance of blank, sample and control, respectively. The half maximal inhibitory concentration $\left(\mathrm{IC}_{50}\right)$ was calculated from the Prism (GraphPad 5.0, Dose-response - Inhibition) curve obtained by plotting the percentage inhibition against the log concentration. 


\section{Nitric oxide radical scavenging assay}

The sample MCFE $(25-800 \mathrm{mg} / \mathrm{ml})$ with nitric oxide was determined by the nitrite detection method described by Alderton et al. ${ }^{20}$ The nitric oxide was generated from $100 \mathrm{nM}$ sodium nitroprusside in $10 \mathrm{mM}$ phosphate buffer ( $\mathrm{pH} 7.4$ ) and measured by Griess reaction. The reaction mixture containing $10 \mathrm{mM}$ sodium nitroprusside in phosphate buffer. Griess reagent was added to the aliquot to homogenize after the incubation at $37^{\circ} \mathrm{C}$ for 4 hours. The amount of nitrite formed was measured at $546 \mathrm{~nm}$ and referred to the absorbance of standard nitrites. The mixture without the sample extract was used as control and compared with that of the Ascorbic acid as standard.

The Percentage of Nitric oxide free radical scavenging activity was calculated by the following formula:

Percentage Nitric oxide free radical inhibition $(\%)=\left[\left(\mathrm{A}_{\text {blank }}-\mathrm{A}_{\text {sample }}\right) /\right.$ $\left.\left(\mathrm{A}_{\text {blank }}-\mathrm{A}_{\text {control }}\right)\right] \times 100$

Where $\mathrm{A}_{\text {blank }}, \mathrm{A}_{\text {sample }}$ and $\mathrm{A}_{\text {control }}$ are the absorbance of blank, sample and control, respectively. The half maximal inhibitory concentration $\left(\mathrm{IC}_{50}\right)$ was calculated from the Prism (GraphPad 5.0, Dose-response - Inhibition) curve obtained by plotting the percentage inhibition against the log concentration.

\section{Anticholinesterasic activity assays}

AChE assay was assessed by using the colorimetric method as explained by Ellman et al, with slight modifications acclimatized for the enzymatic activity in supernatants of mice brain. ${ }^{21}$

\section{In vitro inhibition of AChE enzyme}

AChE inhibition of MCFE was considered by the proposed method by Ellman et al with slight modifications. ${ }^{21} \mathrm{AChE}$ activity was evaluated using the Acetylthiocholine iodide as substrate and 5, 5 - Dithiobis [2-nitrobenzoic acid] as a chromogen. The mice brain homogenate was sourced as acetylcholinesterase enzyme. Male mice of Swiss albino strain of about $20 \mathrm{~g}$ body weight sacrificed by exerting cervical dislocation. The brain was excised immediately and homogenized using $0.1 \mathrm{mM}$ sodium phosphate buffer ( $\mathrm{pH} 7.0)$ and stored at $-80^{\circ} \mathrm{C}$ till the use. MCFE (50-800 $\mu \mathrm{g} / \mathrm{ml}$ ) mixed in $2.6 \mathrm{ml}$ of $0.1 \mathrm{mM}$ sodium phosphate buffer ( $\mathrm{pH} 7.0$ ) and $5 \mu \mathrm{l}$ of brain homogenate containing crude enzyme. The mixture was incubated for $5 \mathrm{~min}$ at $25^{\circ} \mathrm{C}$. The reaction was initiated by adding $20 \mu \mathrm{l}$ of Acetylthiocholine iodide. The inhibition of AChE was measured at $412 \mathrm{~nm}$; the yellow colour formation indicates the hydrolysis of acetylthiocholine into 2-nitro-5-sulfidobenzene carboxylate anion due to the action of DTNB with thiocholine for $10 \mathrm{~min}$.

The Percentage of AChE inhibitory activity was calculated by the following formula:

Percentage AChE inhibition $(\%)=\left[\left(\mathrm{A}_{\text {blank }}-\mathrm{A}_{\text {sample }}\right) /\left(\mathrm{A}_{\text {blank }}-\mathrm{A}_{\text {control }}\right)\right] \times 100$

Where $\mathrm{A}_{\text {blank }}, \mathrm{A}_{\text {sample }}$ and $\mathrm{A}_{\text {control }}$ are the absorbance of blank, sample and control, respectively. The half maximal inhibitory concentration $\left(\mathrm{IC}_{50}\right)$ was calculated from the Prism (GraphPad 5.0, Dose-response - Inhibition) curve obtained by plotting the percentage inhibition against the log concentration.

\section{Ex vivo inhibition of AChE enzyme}

Six Swiss albino male mice were placed in each group and treated with two different doses of MCFE (100 and $200 \mathrm{mg} / \mathrm{Kg}$, p.o) and Neostigmine $(0.5 \mathrm{mg} / \mathrm{Kg}$, i.p) for a period of 15 days. The animals in control group received the same volume of $5 \%$ CMC (administered with vehicle). On $15^{\text {th }}$ day, the mice were decapitated using cervical dislocation method. The whole brain was dissected out quickly in an ice- cold plate and homogenized using 10 volumes of ice cold $20 \mathrm{mM}$ phosphate buffer $(\mathrm{pH}$ 7.4). The homogenates were centrifuged at $10,000 \mathrm{rpm}$ for $10 \mathrm{~min}$. The supernatant was sourced for acetylcholinesterase enzyme estimation. The total AChE activity was measured by the method proposed by Ellman et al. (1961). Homogenate was mixed with a buffered solution containing Ellman's reagent (10 mM DTNB) and Acetylthiocholine iodide $(0.8 \mathrm{mM})$. Rate of Hydrolysis was measured at $415 \mathrm{~nm}$ for $3 \mathrm{~min}$ with an interval of $30 \mathrm{sec}$, estimated by the formation of thiolate dianion of DTNB. The percentage of inhibition was calculated by comparing the enzymatic activity of AChE in brain homogenate aliquots with mice treated with 5\% CMC. The Percentage of inhibition of AChE activity was calculated by using the following formula:

Percentage AChE inhibition $(\%)=\left[\left(\mathrm{A}_{\text {blank }}-\mathrm{A}_{\text {sample }}\right) /\left(\mathrm{A}_{\text {blank }}-\mathrm{A}_{\text {control }}\right)\right] \times 100$

Where $\mathrm{A}_{\text {blank }}, \mathrm{A}_{\text {sample }}$ and $\mathrm{A}_{\text {control }}$ are the absorbance of blank, sample and control, respectively. The half maximal inhibitory concentration $\left(\mathrm{IC}_{50}\right)$ was calculated from the Prism (Graph Pad 5.0, Dose-response - Inhibition) curve obtained by plotting the percentage inhibition versus the log concentration.

\section{Statistical analysis}

All activities were carried out in triplicate and the data were expressed as mean \pm standard error mean (S.E.M.). The inhibitory concentration of free radicals by $50 \%,\left(\mathrm{IC}_{50}\right)$ was graphically evaluated by a non linear regression method using Graph Pad Prism (Ver. 5.0) software. ANOVA followed by Duncan's multiple range tests was used to compare the treatments and control groups. Dose response relationship was obtained by linear regression. 95\% $(\mathrm{p}<0.05)$ confidence level were considered as statistically significant.

\section{RESULTS \& DISCUSSION}

\section{In vitro antioxidant assay}

The results of the DPPH and nitric oxide free radical scavenging activity were reported in Table 1 and the $\mathrm{IC}_{50}$ values obtained are shown in Figure 1 \& 2 . It is very clear from the Table that the standard for DPPH free radical scavenging activity quercetin produced maximum percentage inhibition of $88.12+1.04$ as compared to that of the MCFE which produced an inhibition of $76.77 \pm 1.10$. The standard ascorbic acid produced a maximum percentage inhibition of the nitric oxide free radicals of $94.75 \pm 0.36$ at a dose of $800 \mu \mathrm{g} / \mathrm{ml}$ as compared to that of the MCFE which produced an inhibition of $71.74 \pm 0.60$. Further all the standards and MCFE produced a dose dependent inhibition of DPPH and nitric oxide free radicals. This is evident from Figure 1 which was used to determine the $\mathrm{IC}_{50}$ value. The $\mathrm{IC}_{50}$ value of quercetin was found to be $46.22 \mu \mathrm{g} / \mathrm{ml}$ as compared to the MCFE which has an $\mathrm{IC}_{50}$ value of $43.14 \mu \mathrm{g} / \mathrm{ml}$ for DPPH free radical scavenging activity [Figure 2]. Similarly the $\mathrm{IC}_{50}$ value of ascorbic acid was found to be $81.85 \mu \mathrm{g} / \mathrm{ml}$ as compared to the MCFE which has an $\mathrm{IC}_{50}$ value of $148.0 \mu \mathrm{g} / \mathrm{ml}$ for nitric oxide scavenging activity.

\section{In vitro inhibition of AChE enzyme}

The values of in vitro anticholinesterase activity were tabulated in Table 2. The percentage inhibition values of MCFE were found to be in a dose dependent manner as represented in Figure 3. The maximum percentage inhibition was obtained at the dose of $800 \mu \mathrm{g} / \mathrm{ml}$ which produced a maximum inhibition of $76.77 \pm 1.10$. Similarly the in vitro acetylcholinesterase inhibition assay of standard drug neostigmine was found to produce maximum inhibition of $88.12 \pm 1.04$ at a dose of $800 \mu \mathrm{g} / \mathrm{ml}$. The $\mathrm{IC}_{50}$ values of both MCFE and the standard drug were represented in Figure 3 . The $\mathrm{IC}_{50}$ value of MCFE and neostigmine was found to be 31.84 $\mu \mathrm{g} / \mathrm{ml} \& 19.71 \mu \mathrm{g} / \mathrm{ml}$ respectively and this is evident from the analysis that 
Table 1: Inhibition profile of activities of fruit extract of Morinda citrifolia against nitric oxide production \& DPPH radical scavenging activity as free radical scavengers

\begin{tabular}{|c|c|c|c|}
\hline Treatment groups & Dose $(\mu \mathrm{g} / \mathrm{ml})$ & $\begin{array}{c}\text { Nitric oxide production } \\
\text { (\% inhibition) }\end{array}$ & $\begin{array}{l}\text { DPPH decolouration } \\
\text { (\% inhibition) }\end{array}$ \\
\hline \multirow[t]{6}{*}{ Morinda citriflolia } & 25 & $15.07 \pm 0.38$ & $58.85 \pm 0.09$ \\
\hline & 50 & $17.50 \pm 2.15$ & $62.51 \pm 0.05$ \\
\hline & 100 & $22.79 \pm 1.66$ & $65.34 \pm 1.93$ \\
\hline & 200 & $26.26 \pm 1.51$ & $68.65 \pm 0.41$ \\
\hline & 400 & $28.73 \pm 1.29$ & $72.84 \pm 0.68$ \\
\hline & 800 & $71.74 \pm 0.60$ & $76.77 \pm 1.10$ \\
\hline \multirow[t]{6}{*}{ Quercetin } & 25 & - & $52.12 \pm 0.72$ \\
\hline & 50 & - & $67.28 \pm 0.46$ \\
\hline & 100 & - & $75.98 \pm 0.95$ \\
\hline & 200 & - & $81.82 \pm 1.02$ \\
\hline & 400 & - & $84.54 \pm 1.24$ \\
\hline & 800 & - & $88.12 \pm 1.04$ \\
\hline \multirow[t]{6}{*}{ Ascorbic acid } & 25 & $73.28 \pm 0.90$ & - \\
\hline & 50 & $89.99 \pm 0.36$ & - \\
\hline & 100 & $91.01 \pm 0.78$ & - \\
\hline & 200 & $90.51 \pm 2.18^{*}$ & - \\
\hline & 400 & $93.50 \pm 0.36^{*}$ & - \\
\hline & 800 & $94.75 \pm 0.36^{*}$ & - \\
\hline
\end{tabular}

All assays were performed in triplicate. Enzyme inhibition is expressed as percentage of control. Each value represents mean \pm S.E.M.

Table 2: In vitro Anticholinesterase activity of Morinda citrifolia

\begin{tabular}{ccc}
\hline Treatment groups & Dose $(\mu \mathrm{g} / \mathrm{ml})$ & AChE inhibition $(\%)$ \\
\hline Morinda citrifolia & 25 & $58.85 \pm 0.09$ \\
50 & $62.51 \pm 0.05$ \\
100 & $65.34 \pm 1.93$ \\
200 & $68.65 \pm 0.41$ \\
400 & $72.84 \pm 0.68$ \\
Neostigmine & 800 & $76.77 \pm 1.10$ \\
& 25 & $52.12 \pm 0.72$ \\
& 50 & $67.28 \pm 0.46$ \\
& 100 & $75.98 \pm 0.95$ \\
& 200 & $81.82 \pm 1.02$ \\
400 & $84.54 \pm 1.24$ \\
& 800 & $88.12 \pm 1.04$ \\
\hline
\end{tabular}

All assays were performed in triplicate. Enzyme inhibition is expressed as percentage of control. Each value represents mean \pm S.E.M.

Table 3: Effects of chronic administration of Morinda citrifolia (100 and $200 \mathrm{mg} / \mathrm{kg}$ p.o.) and neostigmine ( $0.5 \mathrm{mg} / \mathrm{kg}$ i.p.) on AChE activity in mice brain.

\begin{tabular}{ccc}
\hline Treatment groups & Dose $(\mathrm{mg} / \mathrm{kg})$ & AChE inhibition $(\%)$ \\
\hline Neostigmine & 0.5 & $62.1 \pm 2.5^{*}$ \\
Morinda citrifolia & 100 & $37.8 \pm 2.1^{*}$ \\
& 200 & $46.8 \pm 2.9^{*}$ \\
\hline
\end{tabular}

All assays were performed in triplicate. Enzyme inhibition is expressed as percentage of control (DMSO-treated mice). Each value represents mean \pm S.E.M. ANOVA followed by Duncan's test. ${ }^{\star} \mathrm{P}<0.05$; significant from control. is carried out using non linear regression analysis for plotting the line of best fit for the observed values in the Table 2 using statistical methods.

\section{Ex vivo inhibition of AChE enzyme}

The ex vivo AChE inhibition assay was tabulated in Table 3. The standard drug neostigmine showed a percentage inhibition of $62.1 \pm 2.5$. The MCFE showed a percentage inhibition of $37.8 \pm 2.1 \& 46.8 \pm 2.9$ at a dose of 100 \& $200 \mathrm{mg} / \mathrm{kg}$ respectively and this proved a dose dependent percentage inhibition of acetylcholinesterase activity. Further the data was analysed for significance of $\mathrm{P}$ value. The standard drug and MCFE treated group was compared with the control group. All the three treated groups showed a significant value of $\mathrm{P}<0.05$ as compared to that of control This indicates that the activity of acetylcholinesterase enzyme has significantly decreased after treatment with the standard drug and MCFE.

The present study investigated the neuroprotective activity of Morinda citrifolia and it was identified by both in vitro and ex vivo techniques that the phytoconstituents in the plant has the ability to improve the learning and memory function by inhibiting the acetylcholinesterase. Further the antioxidant potential of the plant was also evident from the DPPH and nitric oxide scavenging activity. Future studies may be designed for chronic administration of Morinda citrifolia to further investigate the effect on in vivo experimentation and also to identify the safety and efficacy parameters at both preclinical and clinical stages.

\section{ACKNOWLEDGEMENT}

The authors sincerely thank the management of Sri Ramachandra University for providing us with all the facilities for the successful completion of the project. 


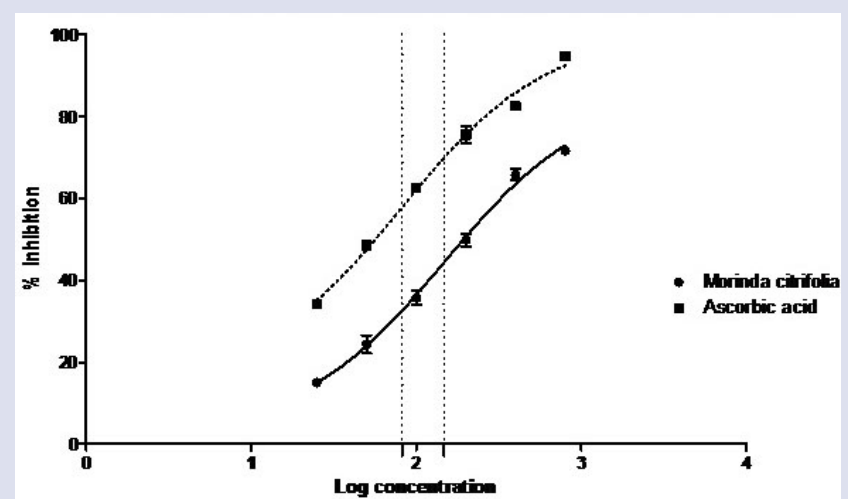

Figure 1: Nitric oxide scavenging assay of Morinda citrifolia fruit extract

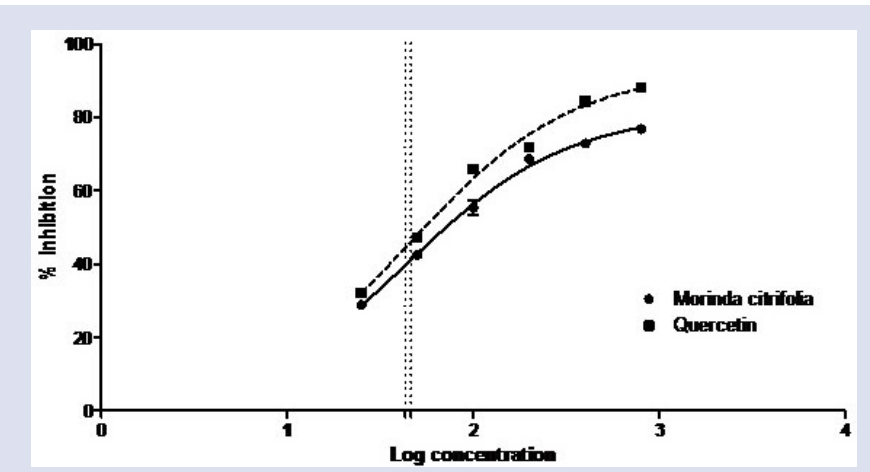

Figure 2: DPPH scavenging assay of Morinda citrifolia fruit extract

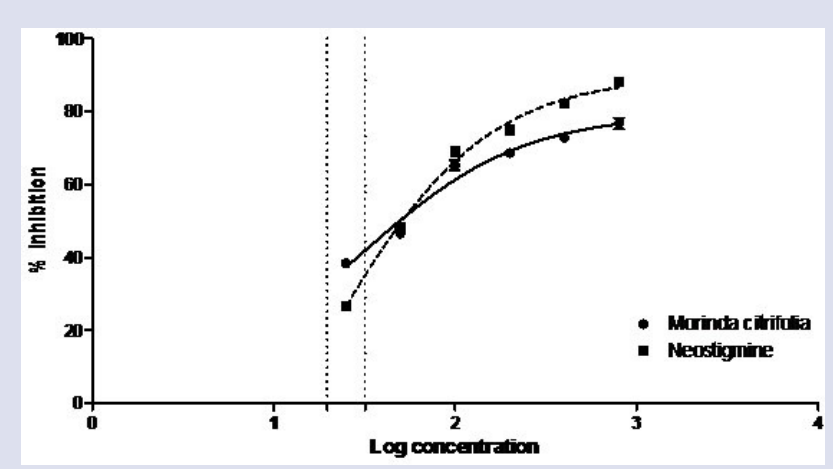

Figure 3: In vitro anticholinesterase activity of Marinda citrifolia

\section{SOURCES OF FUNDING}

This project is funded by Growth and Advancement Towards Excellence (GATE) Research Grants to Young Faculty of Sri Ramachandra University \& Career Award for Young Teachers (CAYT) - All India Council for Technical Education (AICTE), New Delhi

Conflicting Interest (If present, give more details): Nil

\section{ABBREVIATIONS USED}

MCFE: Morinda citrifolia fruit extract; AChE: Acetylcholinesterase; IC $_{50}$ : Half maximal inhibitory concentration; DPPH: 1, 1-diphenyl-2-picrylhydrazyl radical; NO: Nitric oxide.

\section{REFERENCES}

1. Anand $P$, Singh B. A review on cholinesterase inhibitors for Alzheimer's disease. Arch. Pharmacal Res. 2013;36(4):375-99.

2. Coyle JT, Price DL, DeLong MR. Alzheimer's disease: a disorder of cortical cholinergic innervation. Science. 1983;219(4589):1184-90.

3. Singh M, Kaur M, Kukreja H, Chugh R, Silakari O, Singh D. Acetylcholinesterase inhibitors as Alzheimer therapy: from nerve toxins to neuroprotection. Eur. J. Med. Chem. 2013;70:165-88.

4. Parsons CG, Danysz W, Dekundy A, Pulte I. Memantine and cholinesterase inhibitors: complementary mechanisms in the treatment of Alzheimer's disease. Neurotoxic. Res. 2013;24(3):358-69.

5. Essa MM, Vijayan RK, Castellano-Gonzalez G, Memon MA, Braidy N, Guillemin GJ. Neuroprotective effect of natural products against Alzheimer's disease. Neurochemistry. Res. 2012;37(9):1829-42.

6. Kumar GP, Khanum F. Neuroprotective potential of phytochemicals. Pharmacognosy. Rev. 2012;6(12):81.

7. Khare CP. Indian medicinal plants: an illustrated dictionary. Springer Science \& Business Media. 2008.p.421.

8. Assi RA, DarwisY, Abdulbaqi IM, Vuanghao L, Laghari MH. Morinda citrifolia (Noni): A comprehensive review on its industrial uses, pharmacological activities, and clinical trials. Arabian J. Chem 2015. doi.org/10.1016/j.arabjc.2015.06.018

9. Muralidharan P, Kumar VR, Balamurugan G. Protective effect of Morinda citrifolia fruits on $\beta$-amyloid (25-35) induced cognitive dysfunction in mice: An experimental and biochemical study. Phytother. Res. 2010;24(2):252-8.

10. Pachauri SD, Tota S, Khandelwal K, Verma PR, Nath C, Hanif K, et al. Protective effect of fruits of Morinda citrifolia L. on scopolamine induced memory impairment in mice: a behavioral, biochemical and cerebral blood flow study. J. Ethnopharmacology. 2012;139(1):34-41.

11. Harada S, Hamabe W, Kamiya K, Satake T, Yamamoto J, Tokuyama S. Preventive effect of Morinda citrifolia fruit juice on neuronal damage induced by focal ischemia. Biol. Pharm. Bull. 2009;32(3):405-9.

12. Muralidharan P, Srikanth J. Anti-epileptic activity of Morinda citrifolia linn fruit extract. E-J. Chem. 2010;7(2):612-6.

13. Köktürk S, Ceylan S, Etus V, Yasa N, Ceylan S. Morinda citrifolia L. (Noni) and memantine attenuate periventricular tissue injury of the fourth ventricle in hydrocephalic rabbits. Neural Regener. Res. 2013;8(9):773.

14. Pandy V, Narasingam M, Mohamed Z. Antipsychotic-like activity of Noni (Morinda citrifolia Linn.) in mice. BioMedCentral Complementary Altern. Med. 2012;12(1):186

15. Muto J, Hosung L, Uwaya A, Isami F, Ohno M, Mikami T. Morinda citrifolia fruit reduces stress-induced impairment of cognitive function accompanied by vasculature improvement in mice. Physiol. Behavior. 2010;101(2):211-7.

16. Harada S, Fujita-Hamabe W, Kamiya K, Mizushina Y, Satake T, Tokuyama S. Morinda citrifolia fruit juice prevents ischemic neuronal damage through suppression of the development of post-ischemic glucose intolerance. J. Nat. Med. 2010;64(4):468-73.

17. Pachauri SD, Verma PR, Dwivedi AK, Tota S, Khandelwal K, Saxena JK, et al. Ameliorative effect of Noni fruit extract on streptozotocin-induced memory impairment in mice. Behav. Pharmacology. 2013;24(4):307-19.

18. Praveen K, Yellamma K. In silico identification of suitable acetylcholinesterase inhibitors from Morinda citrifolia Linn with reference to Alzheimer's disease. Int J. Pharm. Sci. Res. 2014;5(12):5474.

19. Yokozawa T, Dong E, Wu-Liu Z, Shimidzu M. Antioxidant activity of flavones and flavonols In vitro. Phytotherapy. Res. 1997;11(6):446-9.

20. Alderton WK, Cooper CE, Knowles RG. Nitric oxide synthases: structure, function and inhibition. Biochemistry. J. 2001;357(3):593-615

21. Ellman GL, Courtney KD, Andres V, Featherstone RM. A new and rapid colorimetric determination of acetylcholinesterase activity. Biochemistry. Pharmacology. 1961;7(2):88-95 
GRAPHICAL ABSTRACT

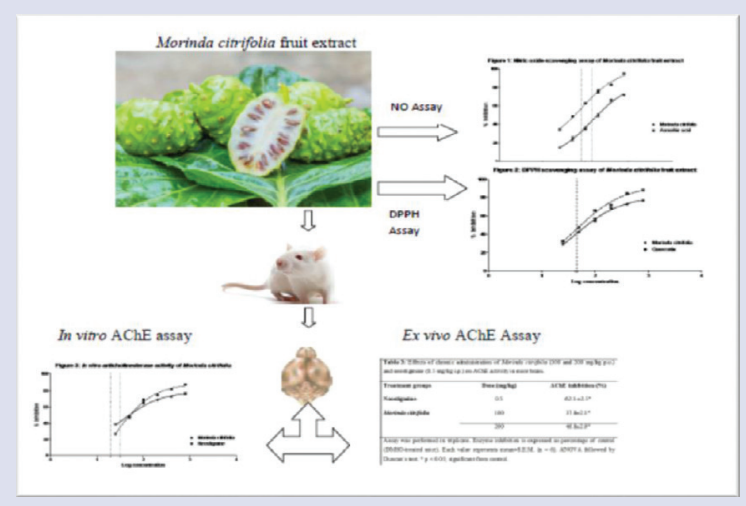

\section{SUMMARY}

- The present study is focused to identify the neuroprotective activity of Morinda citrifolia fruit extract (MCFE) on in vitro and ex vivo animal model by inhibition of acetylcholinesterase (AChE), an enzyme target used for the treatment of Alzheimer's disease.

- Acetylcholinesterase inhibition assay was performed by in vitro method and the $I_{50}$ value of MCFE and neostigmine was found to be $31.84 \mu \mathrm{g} / \mathrm{ml} \& 19.71$ $\mu \mathrm{g} / \mathrm{ml}$ respectively.

- In ex vivo AChE inhibition assay the standard drug neostigmine showed a percentage inhibition of $62.1 \pm 2.5$. The MCFE showed a percentage inhibition of $37.8 \pm 2.1 \& 46.8 \pm 2.9$ at a dose of $100 \& 200 \mathrm{mg} / \mathrm{kg}$ body weight of the animal respectively and this proved a dose dependent percentage inhibition of acetylcholinesterase activity.

- The present study investigated the neuroprotective activity of MCFE and it was identified by both in vitro and ex vivo techniques that the phytoconstituents has the ability to improve the learning and memory function by inhibiting the acetylcholinesterase.

\section{ABOUT AUTHORS}

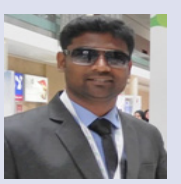

Mr. J. Srikanth is working as Assistant professor in the Department of Pharmacology, Faculty of Pharmacy, Sri Ramachandra University and has got 8 years of teaching \& research experience. He is currently pursuing Ph.D at Sri Ramachandra University. He has been awarded "Career Award for Young Teachers" (CAYT) - 2015 from All India Council for Technical Education (AICTE) for his Ph.D research proposal. He has also received "Growth and Advancement Towards Excellence" (GATE) - 2013 research project grant for young faculty from Sri Ramachandra University. His research area of interest includes Neuropharmacological screening of crude extracts, herbal \& polyherbal formulations, In-silico docking analysis, Alternative to animal testing. He is a life member of APTI, LASA \& SNCl.

Cite this article: Jeyabalan S, Subramanian K, Cheekala UMR, Krishnan C. In vitro \& ex vivo Acetylcholinesterase Inhibitory Activity of Morinda citrifolia Linn (Noni) Fruit Extract. Pharmacog J. 2017;9(6):900-5. 